\title{
Tradisi "Hippun" Sebagai Model Permersatu Masyarakat Multikultural (Studi Pada Penduduk Ragam Etnis dan Budaya Di Wilayah Kabupaten Lampung Selatan)
}

\author{
Abdul Syani, Pairulsyah, Suwarno, Damar Wibisono* \\ Jurusan Sosiologi, Fakultas IImu Sosial dan IImu Politik, Universitas Lampung, Bandar Lampung, 35141 \\ *email korespondensi: damar.wibisono@yahoo.co.id
}

\begin{abstract}
Cultural plurality in Lampung society cannot be avoided or rejected. For some people, the plurality of cultural customs is considered to threaten the ethnological existence of the group. Other parties are still there who reject cultural pluralism because it is considered as a trigger for social conflicts and anarchic actions in people's lives. Meskipin the parties realized that the Lampung community is a pluralistic society, but not all can realize open social relations with mutual respect, there are still parties who find it difficult to accept the existence of other groups. Faced with this fact, the Lampung indigenous people have the tools of archipelago insight and the philosophy of Sang Bumi Ruwa Jurai and the life principles of "hippun" which tradition in daily living behavior, especially in each will make planning and or do joint work for common interests.
\end{abstract}

This study aims to find out the tradition of "Hippun" as a unifying model of a multicultural society; efforts to preserve the tradition of "Hippun" as a unifying model of a multicultural society; and to analyze the development of a unifying model of a multicultural society in South Lampung.

This study uses a qualitative approach. This approach is intended as a process of analytical understanding based on the empirical paradigm to investigate various events and efforts to preserve the stability of multicultural society with a model of the implementation of piil pesenggiiri local wisdom values, especially in the South of the Republic of Indonesia.

Research results show that the tradition of "Hippun" can be used as a model / tool unifying multicultural communities in Lampung Province especially and Indonesia in general. In the tradition "hippun contains 5 elements of the principle of hidu, namely: 1) Uttung-sebagi; 2) Debts; 3) All-time; 4) Hippun-nufakat; and 5) Secrets. With the existence of this element, Hippun can encourage the creation of harmony, peace and strengthening the bonds of community unity. The characteristics of community unity, among others, are the existence of togetherness, solidarity, sacrifice, willingness to sacrifice and awareness in living in a community, so that there is a desire to always help others.

Keywords: Hippun Tradition, Local Wisdom, Multicultural Society, Unifying Model,

ABSTRAK. Pluralitas budaya dalam masyarakat Lampung tidak bisa dihindarkan apalagi ditolak. Bagi sebagian masyarakat, pluralitas adat budaya dianggap mengancam eksistensi etnologis atas kelompoknya. Pihak lain lagi masih ada yang menolak Pluralisme budaya karena dianggap sebagai pemicu terjadinya konflik sosial dan tindakan anarkis dalam kehidupan masyarakat. Meskipin pihakpihak menyadari bahwa masyarakat Lampung merupakan masyarakat yang plural, akan tetapi tidak semua dapat mewujudkan hubungan sosial yang terbuka saling menghargai, masih ada pihak yang sulit menerima keberadaan kelompok lain. Berhadapan dengan kenyataan itu, masyarakat adat Lampung memiliki piranti wawasan nusantara dan perangkat filosofi Sang Bumi Ruwa Jurai dan prinsip hidup "hippun" yang mentradisi dalam perilaku hidup sehari-hari, khususnya dalam setiap akan membuat perencanaan dan atau melakukan pekerjaan bersama untuk pepentingan bersama.

Penelitian ini bertujuan untuk mengetahui tradisi "hippun" sebagai model pemersatu masyarakat multikultural; upaya melestarikan tradisi "hippun" sebagai model pemersatu masyarakat multikultural; dan untuk menganalisis pengembangan model pemersatu masyarakat multikultural di Lampung Selatan.

Penelitian ini menggunakan pendekatan kualitatif. Pendekatan ini dimaksudkan sebagai proses pemahaman analitis berdasarkan paradigma empirik untuk menyelidiki berbagai peristiwa dan upaya pemeliharaan stabilitas masyarakat multikulturalm dengan model implementasi nilai-nilai kearifan lokal piil pesenggiiri, khususnya di Lampng Selatan. 
Hasil penelitan menunjukkan bahwa tradisi "hippun" dapat dijadikan sebagai model/alat pemersatu masyarakat multikultural di Provisinsi Lampung khusunya dan Indonesia pada umumnya. Dalam tradisi "hippun mengandung 5 unsur prinsip hidu yaitu: 1) Uttung-sebagi; 2) Utang-sebayakh; 3) Semaya-setunggu; 4) Hippun-nufakat; dan 5) Ukhik-sepati. Dengan adanya unsur tersebut, hippun dapat mendorong terciptanya kerukunan, perdamaian dan penguatan ikatan persatuan warga masyarakat. Adapun ciri adanya persatuan masyarakat, antara lain adalah adanya kebersamaan, kesetiakawanan, kesenasiban, kerelaan berkorban dan adanya kesadaran dalam hidup bermasyarakat, sehingga timbul keinginan untuk selalu membantu sesama.

Kata Kunci: Kearifan Lokal, Masyarakat Multikultural, Model Pemersatu, Tradisi Hippun

\section{Pendahuluan}

Masyarakat (multicultural society) adalah masyarakat yang terdiri dari banyak kebudayaan dan antara pendukung kebudayaan saling menghargai satu sama lain. Masyarakat multikultural terdiri dari berbagai elemen, baik itu suku, ras, golongan, dll yang hidup dalam suatu kelompok dan menetap di wilayah tertentu. Setiap masyarakat menghasilkan kebudayaannya masingmasing yang akan menjadi ciri khas bagi masyarakat tersebut.

Bagi Masyarakat adat Lampung yang multi-kultur-etnis terhimpun dalam motto/semboyan "Sang Bumi Ruwa Jurai". Semboyan ini diartikan sebagai keragaman (plural) kebudayaan, yang terdiri dari 2 (dua) kelompok adat budaya besar yang berbeda, yaitu adat saibatin dan pepadun. Akan tetapi tidak sedikit pihak yang kurang memahami makna simbol Sang Bumi Ruwa Jurai tersebut. Demikian juga dengan hadirnya etnis pendatang, ternyata sebagian mereka belum dapat (bahkan tidak) beralkurturasi (berdampingan) atau bergabung dengan kedua jurai budaya Lampung yang telah ada, sehingga seringkali menimbulkan perselisihan/ konflik. Dalam simbol budaya Sang Bumi Ruwa Jurai tidak ada kategori ulun Lampung dan pendatang; ini tidak sesuai dengan pemahaman unsur-unsur piil pesenggiri, terutama unsur nemuinyiman. Justru kelompok pendatang diposisikan sebagai ulun Lampung pada kedua kelompok budaya itu, yaitu pepadun dan saibatin secara bebas dan terbuka, sesuai pilihan, teritorial pemukinan dan penetapan golongan ke dalam warga adat di mana mereka bermukim tetap.

Namun demikian dalam kenyataannya masih ada pandangan bahwa etnik tertentu dianggap lebih tinggi atau lebih baik daripada etnik yang lain. Pandangan ini merupakan konsekuensi dari etnosentrisme masing-masing kelompok masyarakat. Adanya diversitas (keragaman) masyarakat adat ini membuka peluang timbulnya ancaman dan rasa tidak nyaman bagi sebagian warga masyarakat. Hal ini dapat dirasakan bahwa kadangkala seseorang enggan untuk bergaul atau berada diantara orang-orang yang berbeda etnis dan budaya. Bukan berarti toleransi dalam masyarakat Lampung selalu dapat bertahan tanpa konflik. Kebersamaan dalam semboyan Sang Bumi Ruwa Jurai dapat terancam, jika kepentingan sepihak makin ekstrim, nilai-nilai budaya dibangun untuk kepentingan kelompok, terjadi persaingan dan ketimpangan penguasaan di bidang usaha, serta terjadinya perlakuan diskriminatif.

Berhadapan dengan kenyataan itu, masyarakat adat Lampung memiliki piranti wawasan nusantara dan perangkat filosofi Sang Bumi Ruwa Jurai dan prinsip hidup "hippun" yang mentradisi dalam perilaku hidup seharihari, khususnya dalam setiap akan 
membuat perencanaan dan atau melakukan pekerjaann bersama untuk pepentingan bersama. Pluralisme adat budaya Lampung justru mendorong semangat untuk berusaha beradaptasi agar tercipta saling memahami, saling berdampingan dan saling menghormati. Dalam perkembangannya dapat dijadikan sebagai wahana dialog antara pluralisme masyarakat untuk saling menyadari dan memahami kultur masing-masing.

Pluralitas masyarakat Lampung dapat terbentuk dari beberapa sumber, yaitu: 1). perbedaan arus informasi dan pengetahuan yang diterima masyarakat; 2). perpindahan penduduk yang mengakibatkan terjadinya keragaman etnik dalam suatu masyarakat; dan 3). Tersedianya sumberdaya di Lampung sebagai wilayah tujuan mencari penghidupan baru. Untuk kategori ini hanya terjadi di propinsi Lampung, dimana orang Jawa menjadi mayoritas $(61,89 \%)$ diikuti dengan Orang asli Lampung justru menjadi minoritas.

Signifikansi pluralisme baru berarti jika dalam aktualitas kegiatan pergaulan hidup sehari-hari antar warga masyarakat berjalan secara harmonis, yaitu membiasanya kegiatan yang beragam, nilai-nilai berbeda dapat dijalankan tanpa kekhawatiran, struktur sosial atau organisasi yang beraneka macam, sistem ide yang tidak tunggal, dan berbagai institusi hadir di tengah masyarakat dan masing-masing menunjukkan keberadaanya secara bebas berakulturasi.

Masyarakat adat Saibatin (sebatin) terdiri dari ragam marga yang tersebar di berbagai wilayah Lampung; pada mulanya secara umum tersebar di kawasan pesisir pantai, kemudian pada dekade selanjutnya tersebar juga di daerah pedalaman dan sektor perkotaan. Demikian juga sebaliknya masyarakat adat Lampung Pepadun yang umumnya bermukim didaerah pedalaman Lampung, kemudian tersebar dan membaur (inkulturasi) dengan kelompok masyarakat lainnya, baik dalam lingkungan 2 kelompok budaya secara umum, maupun dalam lingkungan jurai marga atau kebuawaian dari masing-masing kelompok budaya tersebut [1].

Berbeda dengan kelompok pendukung Adat Pepadun, yang memberikan peluang secara lebih longgar kepada setiap seseorang untuk meningkatkan kedudukannya dalam status adatnya. Pengembangan subkelompok menjadi kelompok kelompok sederajat, melalui proses Cakak Pepadun. Cakak Pepadun adalah salah satu upacara daur hidup masyarakat darah Lampung.

Profil masyarakat adat Saibatin secara ideal memiliki pola pergaulan hidup dengan prinsip musyawarah dan mufakat. Warga masyarakat adat Saibatin secara umum merupakan sejumlah kolektivitas sosial yang masing-masing memiliki aturan internal tersendiri. Secara kultural masyarakat adat Saibatin merupakan kesatuankesatuan hidup yang diatur oleh peraturan-peraturan yang berasal dari norma-norma sosial dan hukum adat yang hidup berkembang dalam masyarakat bersangkutan. Eksitensi institusi perwatin adat merupakan wadah penyimbang adat dalam setiap hippun (musyawarah), terutama mengenai urusan adat dan kemasyarakatan. Seorang penyimbang adat mempunyai kewenangan untuk membuat keputusan hasil musyawarah. Kewenangan dan fatwanya secara internal dipatuhi sebagai norma hukum yang dapat mengatur dan melindungi stabilitas hubungan sosial antar warga, termasuk keserasian hubungan masyarakat dengan alam sekitar. 
Karakteristik masyarakat adat Saibatin dalam perkembangannya lebih menekankankan pada konsensus dalam upaya penyerasian terhadap berbagai kepentingan masyarakat dan tuntutan zaman. Oleh karena itu dalam masyarakat adat Lampung Saibatin, tradisi hippun merupakan model dalam memelihara dan mempererat hubungan persatuan masyarakat, khususnya masyarakat multikultural.

Mengingat masih tersedianya potensi budaya masyarakat adat setempat dan eksistensi hukum adat yang masih tersimpan dalam kehidupan masyarakat, maka perlu dilakukan penggalian dan revitalisasi budaya secara seksama. Hal ini diharapkan dapat memberikan solusi strategis dalam upaya memotivasi masyarakat agar dapat berpartisipasi aktif dalam mendukung pembangunan daerah yang berwawasan budaya tersebut. Berdasarkan harapan dan kenyataan tersebut, maka perlu dilakukan penelitian empirik dengan judul "Tradisi Hippun sebagai Model Masyarakat Multikultural".

\section{Metode Penelitian}

Penelitian ini menggunakan pendekatan kualitatif. Pendekatan ini dimaksudkan sebagai proses pemahaman analitis berdasarkan paradigma empirik untuk menyelidiki berbagai peristiwa dan upaya pemeliharaan stabilitas masyarakat multikultural dengan model implementasi nilai-nilai kearifan lokal tradisi "Hippun", khususnya di Lampung Selatan.

Penelitian ini dilakukan di Lampung Selatan, terutama pada wilayah-wilayah yang diduga sebagai masyarakat multikultural dan masih kuat menganut pandangan hidup piil pesenggiri sebagai model dalam pemeliharaan stabilitas masyarakat yang bersangkutan. Penelitian ini difokuskan pada implementasi nilai-nilai kearifan lokal "Hippun" pada masyarakat multikultural di Lampung Selatan. Jenis data yang dipergunakan dalam penelitian ini adalah dari berbagai sumber berupa data primer dan data sekunder. Data utama berupa fakta, informasi, dokumen-dokumen, dan opini atau pandangan dan harapan yang diperoleh dari institusi, organisasi dan individu, baik yang langsung maupun yang tidak langsung terlibat dalam situasi yang diteliti. Selain itu juga dilakukan FGD untuk menampung opini atau pandangan dan harapan masyarakat tentang tradisi "Hippun"

Analisis data dilakukan sejak sebelum memasuki/terjun ke lapangan, selama di lapangan dan setelah selesai di lapangan. Sugiyono (2010: 245; Moleong, 2000: 207) menyatakan bahwa "Analisis telah mulai dilakukan sejak merumuskan dan menjelaskan masalah, sebelum terjun ke lapangan dan berlangsung terus sampai penulisan hasil penelitian". Dalam penelitian ini, analisis data lebih difokuskan selama proses di lapangan bersamaan dengan pengumpulan, proses data dan setelah di lapangan. Tahapan analisis data mengikuti proses reduksi data, penyajian data, penarikan kesimpulan dan verifikasi.

\section{Hasil Dan Pembahasan}

\section{Peta Latar Belakang Tradisi Hippun sebagai Model Pemersatu Masyarakat Multikultural}

\section{Tradisi Hippun}

Hippun menurut istilah dalam bahasa Lampung Saibatin, khususnya masyarakat adat Kalianda Lampung Selatan adalah 
musyawarah, mupakat, bubabah, kuppulan, khakot, yang maksudnya jaring aspirasi, rapat atau diskusi. Menurut informan (Hidarudin tokoh masyarakat), bahwa pengertian hippun mirip dengan istilah "Mekhatin/meratin", artinya kumpul bersama (cenderung tidak formal) yang dalam praktiknya adalah untuk keperluan membicarakan sesuatu yang hendak diselesaikan atau disepakati bersama. Jika dipahami, maka artinya sama dengan kegiatan musyawarah. Meratin adat, artinya melakukan (me=kata kerja, predikat) musyawarah mengenai kepentingan adat atau masalah yang berkenaan dengan urusan adat istiadat setempat. Akan tetapi berbeda pengertiannya dengan istilah Perwatin, Prowatin atau Purwatin artinya Penyimbang/dewan adat/ tokoh adat) Adat (subyek), Jadi perwatin adalah para tokoh adat, atau pemimpin/kepala pekon/desa. Lebih lanjut dijelaskan bahwa Perwatin adalah pendukung adat istiadat sebagai pelalu/pelaksana dalam musyawarah adat, sedangkan merwatin adalah kumpul bersama yang berlaku umum, siapa saja, kalangan mana saja berkenan melakukannya. Sedangkan dalam istilah masyarakat Lampung Saibatin Way Lima disebut khakot, masyarakat adat Lampung Barat umumnya menyebutnya dengan istilah "Kuppulan", dan menurut istilah masyarakat adat Lampung Pepadun disebut "Peppung".

Oleh karena penduduk wilayah ini beragam terdiri dari macammacam asal usul, etnis, budaya, dan prinsip hidup, maka dapat disebut "Ragom Mufakat", artinya meskipun wilayah ini dihuni oleh beragam suku, agama, ras dan asal usul, akan tetapi selalu mengutamakan mufakat melalui tradisi kegiatan musyawarah. Hal ini sesuai dengan semboyam atau motto Pemerintah Daerah Kabupaten Lampung Selatan, yaitu "Ragom Mufakat".

Menurut masyarakat adat setempat, hippun dikenal pula dengan istilah lain, yaitu berunding, bubalah atau bupahum. Sedangkan dalam konsep musyawarah, berasal dari kata Syawara yaitu berasal dari bahasa arab yang berarti berunding, urun pendapat dan mengajukan usul kepentingan tertentu. Ada beberapa pandangan tentang pengertian hippun, diantaranya adalah:

1. Hippun merupakan kegiatan kelompok (bersama) dengan sikap rendah hati sebagai usaha untuk memecahkan masalah dan mengambil keputusan bersama..

2. Hippun sebagai tindakan sekelompok orang untuk membahas suatu masalah dengan tujuan untuk mendapatkan solusi. Hippun merupakan cara pengambilan keputusan yang melibatkan dua orang atau lebih atas berbagai kepentingan..

3. Hippun merupakan upaya untuk memecahkan persoalan guna mengambil keputusan bersama yang melibatkan anggota masyarakat yang berkepentingan.

4. Hippun adalah pembahasan untuk menyatukan pendapat dalam penyelesaian suatu masalah yang menyangkut kepentingan bersama.

5. Hippun merupakan membicarakan dan menyelesaikan bersama suatu persoalan dan maksud untuk mencapai kata mufakat atau kesepakatan.

Sementara itu istilah "Buhippun" (bu=ber=melakukan; hippun/kumpul, yaitu mengumpulkan/menghimpun 
(pendapat), menjaring aspirasi; artinya musyawarah utk mupakat (supaya mencapai kesepakatan) terhadap rencana/kegiatan/peristiwa/ masalah tertentu. Istilah ini umumnya digunakan masyarakat Kalianda dan masyarakat adat saibatin sekitar untuk menyebut kegiatan musyawarah. Dalam pengertian yang sama adalah Kuppulan/Kekuppulan (Lampung barat pd umumnya) artinya musyawarah atau rapat; Kuppulan Adat adalah rapat para penyimbang adat; Kuppulan pekon artinya musyawarah kampung/desa. Setiap akan melakukan kegiatan kemasyarakatan/sosial, perencanaan pembangunan, atau acara Nayuh (prosesi resepsi perkawinan adat), maka biasanya didahului dengan rapat penyimbang adat yg disebut Kuppulan adat.

\section{Terjadinya Tradisi Hippun}

Secara sosiologis kehidupan masyarakat merupakan keniscayaan, dimana tiada satu manusiapun yang dapat hidup sendiri tanpa teman, tanpa kelompok, tanpa bergaul dan berkomunikasi antar sesamanya. Dalam pengertian masyarakat adalah berupa sejumlah individu yang hidup bersama dalam waktu yang relatif lama; di dalamnya manusia dapat saling mengerti dan merasa dan mempunyai harapan-harapan sebagai akibat dari hidup bersama itu. Terdapat sistem komunikasi dan peraturanperaturan yang mengatur hubungan antarmanusia dalam masyarakat tersebut [2].

Kerukunan dalam hidup bersama dan bekerjasama dalam mencapai kesejahteraan hidupnya. Sebagaimana disebutkan dalam QS AI Kafirun ayat 6 "Lakum Dii Nukum Waa Liya Diim" yang artinya "untukmu agamamu, dan untukkulah agamaku". Dalam tafsirnya perintah loyal, teguh, yakin dan percaya sepenuhnya dengan iman terhadap aqidah bagi pemeluk agama masingmasing. Akan tetapi secara duniawi dengan takdir yang beragam, maka dalam hubungan sosial kemasyarakatan, bukan berarti tertutup untuk saling menjauh, berpisah, sendirisendiri secara ekslusif, tidak saling tegur sapa, akan tetapi dengan perbedaan itu justru harus mampu hidup berdampingan saling menghormati dan rukun dalam hidup bersama.

Demikian pula halnya dengan kehidupan masyarakat yang multikultural dengan banyak perbedaan, seperti perbedaan etnis, asal usul, bahasa, adat istiadat, pandangan hidup, pekerjaan dan profesi, ilmu pengetahuan dan tingkat pendidikan. Secara etnologis ada kecenderungan dalam perkembangannya terjadi persaingan buruk, curang, perselisihan, dan bahkan saling hambat dan berprasangka buruk antar warga. Dalam kondisi ini kerukunan masyarakat akan semakin terancam, khususnya hubungan intim, kebersamaan dan kesatuan masyarakat semakin melemah. Hal ini disebabkan oleh terpaan kemajuan ilmu pengetahuan dan teknologi baru, baik bidang telekomunikasi, transportasi, budaya luar, persaingan di sektor lapangan pekerjaan, dan lain-lain. Sesuai dengan pemikiran Sorokin [3], bahwa hubungan dan pengaruh timbal balik antara aneka macam gejalagejala sosial (misalnya antara gejala ekonomi dengan agama, keluarga dengan moral, hukum dengan ekonomi, gerak masyarakat dengan politik dan sebagainya). 
Menurut Ridwan Dalom Buwai Runjung [4], bahwa kondisi kehidupan semacam itu sekarang sudah sangat terasa, akan tetapi bukan karena tergerusnya nilai-nilai budaya kebersamaan dan kerukunan antar anggota keluarga dan antar anggota masyarakat, melainkan lebih disebabkan olek tidak seimbangnya perkembangan jumlah individu dan kebutuhan hidup dengan kondisi pemilikan lahan, modal, dan keahlian kerja cenderung tetap, bahkan berkurang. Informan menggambarkan tentang regenerasi lahan yang semakin berkurang akibat terbagi oleh masingmasing anak (rata-rata 4-6 anak dalam 1 keluarga), sementara dalam yang sama tidak ada penambahan lahan baru. Kecuali itu sistem pemeliharaan dan penggarapan lahan dengan cara bagi lahan, bukan bagi hasil, misalnya lahan $6 \mathrm{Ha}$. digarap orang lain, dan setelah tanaman berumur 3-4 tahun lahan dibagi dua, dan seterusnya.

Akibat dari semua itu generasi berikutnya hampir tidak memiliki harta peninggalan untuk bertahan hidup di kampung asal, tidak mampu melanjutkan pendidikan, tidak mampu merubah pekerjaan selain bertani, sehingga pada akhirnya diputuskan untuk hijrah ke wulayah lain untuk memenuhi kebutuhan hidup selanjutnya. Mereka berpencar di mana-mana daerah, ada yang merantau di Serang Banten, ada yang di Tanggerang, Jakarta, Kalimantan, bahkan ada yang bertaruh nasin di Papua. Akibatnya kehidupan bersama yang rukum, kumpul bersama dan saling memelihara kearifan lokal bersaudara dekat, serta hippun/ musyawarah bersama sudah jarang terjadi.

Merasakan kenyataan itu, maka para tokoh adat dan masyarakat mulai merapatkan barisan untuk melakukan hippun secara berkala, bahkan terakhir telah direncanakan untuk membentuk lembaga hippun sebagaimana di daerah lain, seperti di beberapa pekon di Kabupaten Tanggamus.

\section{Makna dan Tujuan Hippun}

Hippun bermakna sebagai suatu kegiatans osial kemasyarakatan dengan tradisi kumpul bersama berlandaskan kehendak mencapai kerukunan bersama. Menurut keterangan informan Dalom Buwai Runjung, bahwa inti sari, pokok pikiran dan tjuan utama dari kegiatan hippun adalah kerukunan masyarakat untuk mencapai kesejahteraan lahir dan batin. Artinya semua kegiatan masyarakat dalam berencana dan bekerja untuk mencapai keberhasilan secara efektif, maka harus dibiasakan dimulai dengan melakukan hippun.

Secara ringkas makna hippun adalah tradisi kegiatan kumpul bersama sebagai indikator adanya kerukunan dalam kehidupan masyarakat dengan tujuan untuk mencapai kesejahteraan bersama. Sedangkan konsekuensi dari penolakan atau kontra sosial dari oknum atau sebagian warga atas kegiatan hippun pada umumnya adalah pembatasan atau bahkan peniadaan hak keikutsertaan berupa usul dan keputusan hippun. Menurut keterangan informan bahwa biasanya sanksi sosial penolakan terhadao tradisi hippun ini adalah berupa pengucilan dalam pergaulan masyarakat. Berbagai informasi dan keputusan hippun tidak tersebar secara menyeluruh, sehingga pihak yang terkucil tidak banyak mengtahui perkembangan pembangunan pekon (deaa). Kondisi sosial semacam ini dalam waktu relatif singkat biasanya akan terjasi konflik laten antar anggota atau kelompok masyarakat, bahkan mungkin bisa 
berkembang menjadi konflik terbuka. Untuk mengatasi hal ini biasanya para tokoh adat setempat mengagendakan masalah ini ke dalam kegiatan hippun, dan dalam hippun inilah masalah dibahas yang untuk selanjutnya diselesaikan secara adil.

Tujuan hippun pada umumnya adalah untuk menyederhakan suatu kesulitan dalam pengambilan keputusan, di samping untuk memberikan kesempatan kepada masyarakat untuk menyelesaikan masalah dari berbagai sudut pandang. Setiap orang berhak menyampaikan pendapatnya, urusan diterima atau ditolak. Hippun dilakukan untuk memperoleh kesepakatan bersama dan dapat dilaksanakan oleh semua peserta dengan penuh tanggung jawab. Tujuan hippun sendiri adalah untuk menyelesaikan masalah dengan tidak merugikan pihak-pihak lain secara adil. Pada prinsipnya keputusan dari musyawarah dapat mencapai mufakat, yaitu mendapatkan persetujuan bersama. Hal ini sesuai dengan Pasal 28 Undang-Undang Dasar 1945 yang menyatakan bahwa "Setiap orang berhak atas kebebasan meyakini kepercayaan, menyatakan pikiran dan sikap, sesuai dengan hati nuraninya".

\section{Lingkup Strata Hippun Adat}

Dalam adat Lampung Saibatin pada umumnya terdapat pola hippun adat yang terbagi dalam batasan/ lingkup strata vertikal berdasarkan tingkat Pemerintahan Adat Pusat sampai dengan Pemerintahan Adat bawah dan kelompok warga masyarakat pemekonan, yaitu: 1) hippun marga, 2) hippun tiyuh/ pemekonan, 3) hippun suku, 4) hippun pelambanan, dan 5) hippun warga.

Adapun pembidangan lingkup strata Pemerintahan Marga di Lampung
Selatan pada umumnya adalah sebagai berikut:

\section{Hippun Marga}

Hippun Marga merupakan hippun adat yang dilaksanakan pada lingkup wilayah kekuasaan tingkat Pemerintahan Adat Pusat dipimpin langsung oleh Kepala Marga/ Penyimbang Marga yang bergelar Pengiran atau Dalom di Lamban Balak. Dalam struktur pemerintahan adat ini terdiri dari sejumlah penyimbang adat marga/pusat sebagai perangkat Pemerintahan Adat pusat di bawah kepemimpinan Kepala Adat Marga/pusat. Dalam hal ini kepemimpinan tertinggi marga diduduki oleh seorang Kepala Marga/ Penyimbang Marga yang bergelar Pengiran atau Dalom. Dalam struktur Pemerintahan Adat seorang Kepala Marga dalam menjalankan tugas pokoknya dibantu oleh perangkat adat secara struktural yang terdiri dari tokoh adat yang bergelar Dalom (jika ada), Kariya, Temunggung, Batin, Radin, Raja, Minak dan Mas. Para penyimbang adat ini merupakan perangkat pemerintahan adat (disebut pengisi lamban balak) yang dalam kesehariannya membantu Kepala Marga. Mereka adalah tercatat sebagai pelaksana merangkap peserta hippun (undangan utama).

Setelah semua kegiatan hippun selesai, telah mendapat kesepakatan dan keputusan bersama, maka hasilnya di tuliskan dalam buku keputusan hippun atau buku keputusan rapat adat, lengkap dengan daftar hadir hippun, keputusan-keputusan utama, dan norma-norma hukum adat yang berlaku sejak tanggal ditetapkan, dan seterusnya. Hasil keputusan hippun marga ini kemudian ditembuskan kepada penyimbang-penyimbang tiuh 
(pekon), dan kepada penyimbangpenyimbang suku sebagai dokumen hukum adat yang berlalu sampai hippun adat berikutnya. Adapun skematika / struktur kepenyimbangan Pemerintah Pusat Marga seperti Gambar 1.

\section{Hippun Tiyuh / Pemekonan}

Hippun tiyuh / pemekonan adalah suatu kegiatan mengumpulkan pendapat, atau menjaring aspirasi masyarakat pemekonan dengan agenda yang berkaitan dengan kebijakan kepala tiyuh/penyimbang pekon dan segenap perangkat adatnya, atau berkaitan dengan kepentngan umum, masalah-masalah sosial, atau agenda dengan pendapat / laporanlaporan warga secara berkala. Acara hippun tiyuh ini dilaksanakan di pusat tiyuh di Lamban Balak Kepala Tiuh / Penyimbang Tiyuh dan dipimpin langsung oleh yang bersangkutan atau penyimbang yang mewakilinya. Sedangkan peserta hippun adalah perwakilan dari penyimbang marga, para penyimbang tityuh, tokoh masyarakat, tokoh agama, Pemuda dan warga masyarakat yang dianggap mendukung efektivitas rangkaian hippun. Adapun skematika / struktur kepenyimbangan tiyuh seperti Gambar 2.

Demikian juga skematika / struktur kepenyimbangan tiyuh lainya dari Kepala Tiyuh Batin seperti Gambar 3.

Masing-masing penyimbang tiyuh dan suku dalam wilayah Pemerintahan Adat di tingkat tiyuh dan suku berhak dan berkewajiban untuk mengajak penyimbang-penyimbang lainnya untuk mengerahkan warganya untuk berpartisipasi dalam kegiatan hippun tiyuh.

\section{Hippun Suku}

Pengertian suku dalam adat istiadat Lampung bukan kelompok etnis atau asal usul kelompok adat, akan tetapi diartikan sebagai suatu kelompok kepenyimbangan / kepala adat beserta perangkat adat, yang membawahi kelompok kepala-kepala pelambanan dan warga masyarakat yang dipimpin oleh kepala suku. Suku (kelompok strata adat) merupakan simbol tingkatan stattus dalam struktur pemerintahan adat di bawah kekuasaan Penyimbang Tiyuh. Bisa juga dikatakan sebagai kelompok penyimbang adat perwakilan, jika wilayah domisilinya berada di luar kedudukan wilayah suku dari pemerinahan adat marga (pusat).

Hippun suku adalah kegiatan musyawarah mupakat dalam rangka jaring aspirasi masyarakat dalam arena penyampaian pendapat dalam lingkup kepenyimbangan suku yang dilaksanakan di pusat pemerintahan adat suku, di Lamban (rumah) Kepala Suku setempat). Hippun suku berkaitan dengan pemecahan masalah dalam lingkup suku, baik berupa kepentingan pemerintahan adat, maupun berupa kepentingan warga atau berupa agenda yang bersangkutan dengan masalah perselisihan warga. Adapun skematika / struktur kepenyimbangan suku seperti Gambar 4.

Masing-masing penyimbang suku dan pelambanan dalam wilayah Pemerintahan Adat di tingkat suku dan pelambanan berkewajiban untuk mengajak penyimbang-penyimbang perangkat suku lainnya untuk mengerahkan warganya untuk berpartisipasi dalam kegiatan hippun suku. 


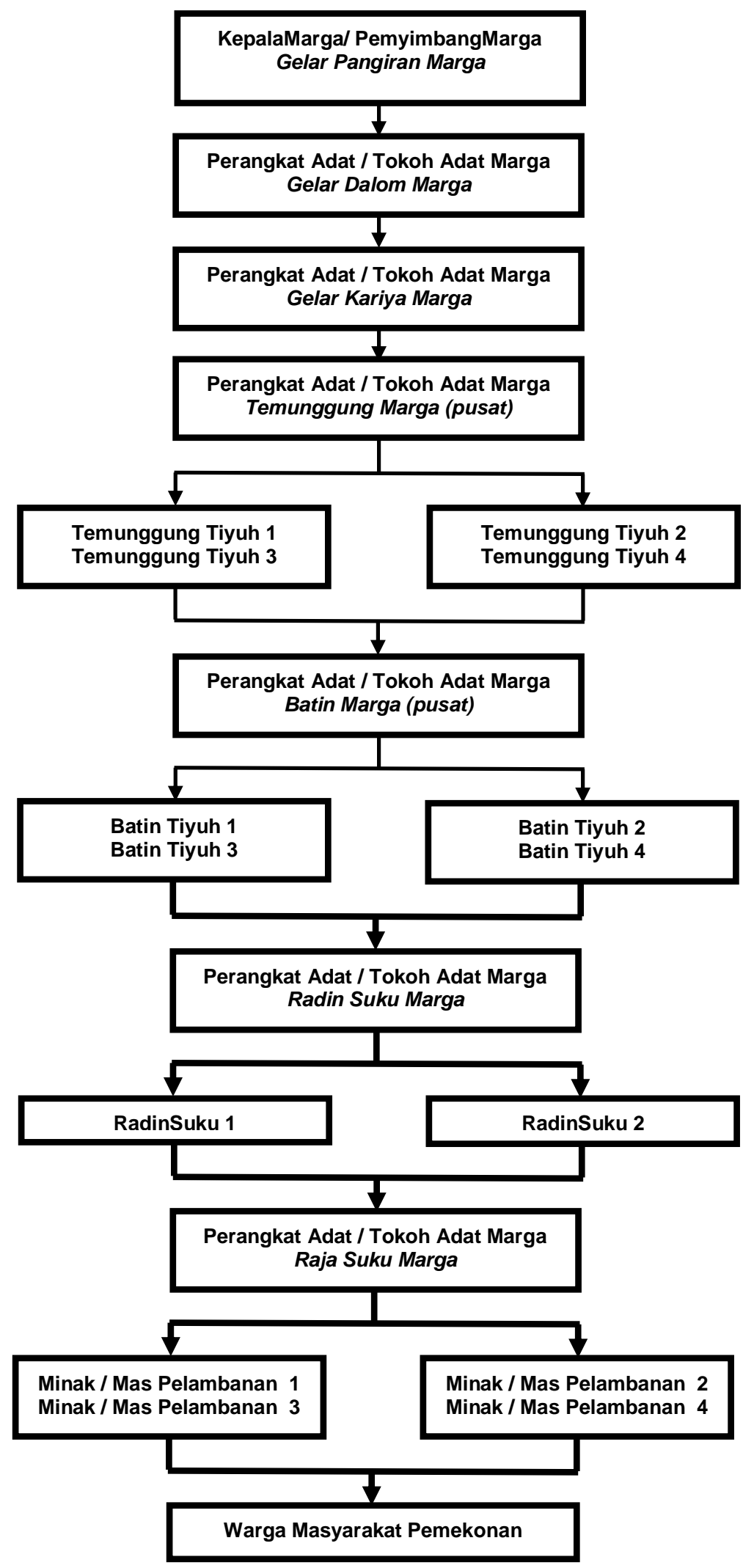

Gambar 1. Skema Hippun 1 

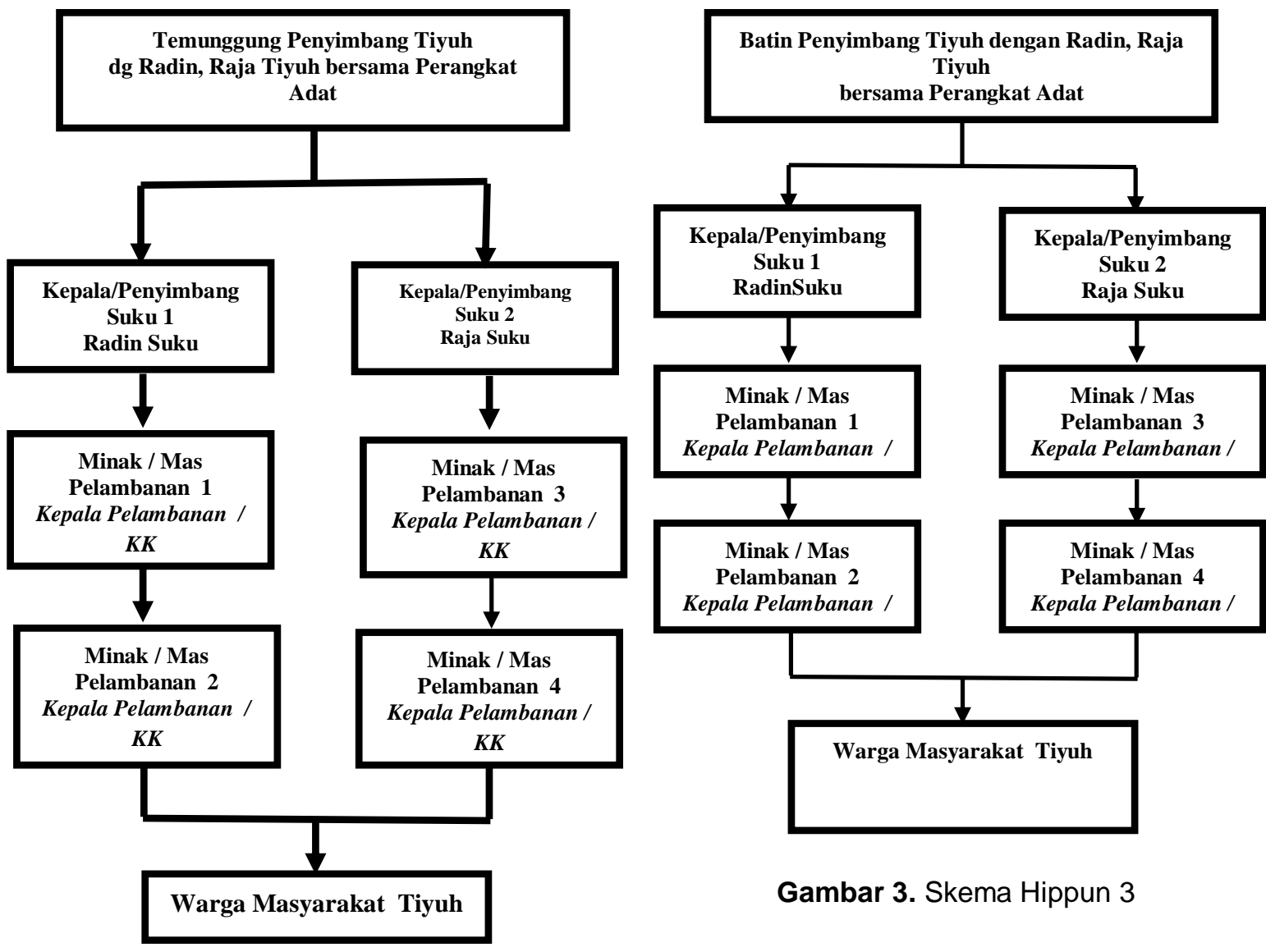

Gambar 2. Skema Hippun 2

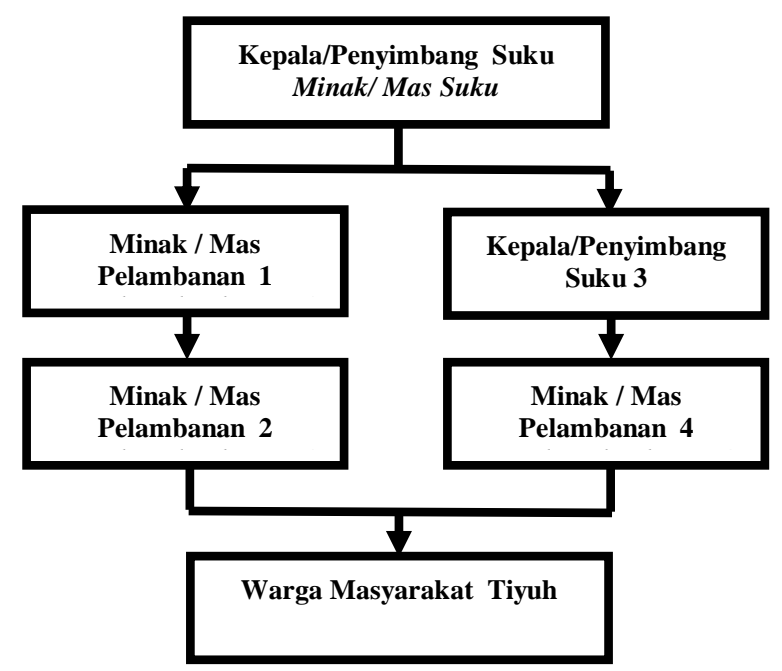

Hippun Pelambanan

Hippun pelambanan adalah kegiatan musyawarah mupakat dalam rangka jaring aspirasi masyarakat atau penyampaian pendapat dalam lingkup kepenyimbangan pelambanan yang dilaksanakan di pusat pemerintahan adat pelambanan, di Lamban (rumah) Kepala Lamban atau kepala keluarga. Hippun pelambanan berkaitan dengan pemecahan masalah dalam lingkup pelambanan, baik berupa kepentingan pemerintahan adat pelambanan,

Gambar 4. Skema Hippun 4 maupun berupa kepentingan warga atau berupa agenda yang bersangkutan dengan masalah perselisihan warga. 
Peserta hippun adalah perwakilan
dari penyimbang suku, tokoh masyarakat, tokoh agama, Pemuda dan warga masyarakat yang dianggap kompeten mendukung efektivitas rangkaian hippun. Mengenai jumlah peserta hippun tergantung pada besar kecilnya agenda yang akan dibahas. Jika hippun menyangkut kebijakan / kepentingan umum yang memerlukan banyak gagasan, biaya dan tenaga dari penyimbang dan warga pelambanan, seperti rencana pembangunan fasilitas ibadah atau untuk kepentingan umum lainnya, maka perlu melibatkan lebih banyak peserta hippun. Adapun skematika / struktur kepenyimbangan pelambanan seperti Gambar 5.

Bagi masing-masing penyimbang pelambanan dandan segenap warga dalam wilayah Pemerintahan Adat di tingkat kepala pelambanan dan warga masyarakat berkewajiban untuk mengajak penyimbang-penyimbang perangkat pelambanan lainnya untuk mengerahkan warga dan atau sesamanya untuk berpartisipasi dalam kegiatan hippun pelambanan.

\section{Hippun Warga}

Hippun warga adalah kegiatan meratin atau kuppulan atau obrolan bersama yang dilakukan oleh perseorangan dengan warga-warga lainnya secara berantai tanpa perencanaan dan koordinasi khusus. Hippun warga ini biasanya dikakukan oleh kelompok warga relatif memiliki persamaan hobi ataurencana tertentu, seperti sesama hobi mancing atau sesama memiliki hobi masu babui (berburu babi) atau sekelompok warga yang memiliki rencana rekreasi bersama pada hari-hari raya makan bersama di pantai, dan lain-lainnya. Hippum bisasanya dimulai dari pencetusan gagasan perorangan, kemudian disampaikan pada warga lain, dan warga lain mengajak warga lainnya lagi, dan seterusnya diketuktularkan, sehingga mencapai kuota yang dinginkan. Selanjutnya kelompok warga ini menentukan tempat dan waktu di mana dan kapan dilaksanakan hippun. Setelah tiba waktunya, lalu hippun warga dilaksanakan dengan agenda tertentu dan mempersiapkan semua fasilitas yang diperlukan bersama.

Dalam hippun warga biasanya dimulai dengan penjelasan waktu, tempat dan agenda utamanya, yaitu menangkut persiapan fasilitas taknis yang diperlukan. Mengenai tata tertib hippun fleksibel, intim, kekeluargaa, dan terbuka, sehingga rangkaian pelaksanaan hippunberjalan santai. Seteleh semua persiapan disepakati bersama, maka kemudian siap dilaksanakan sesuai dengan jadual yang telah disepekati bersama. Dalam hippun warga ini tidak diperlukan perjanjian khusus atau pencatatan keputusan, akan tetapi cukup dengan kepercayaan bahwa masing-masing akan saling setia memegang janji. Adapun skematika / struktur kelompok hippun warga ditunjukkan Gambar 6.



Gambar 5. Skema Hippun 5

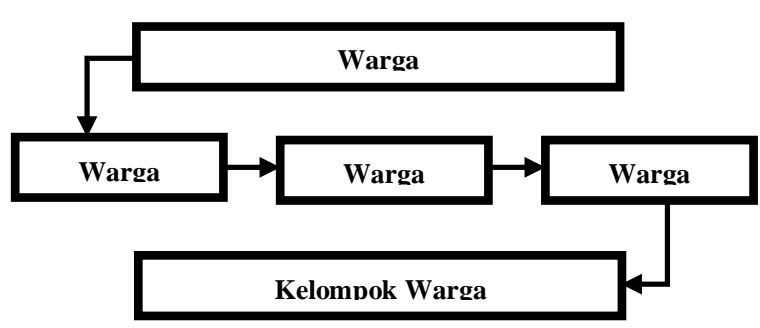

Gambar 6. Skema Hippun 6 
Dari seluruh rangkaian hippun sebagaimana telah dipaparkan di atas, maka dapat dipahami bahwa dengan tradisi hippun dapat memupuk penguatan kebiasaan positif, yaitu mendorong para penyimbang di semua tingkatan dalam struktur adat untuk saling mendukung pembuatan dan pelaksanaan kebijakan yang berkaitan dengan pemeliharaan keadilan dan perlindungan keamanan warga. Kecuali itu dapat mendorong warga dan semua pihak untuk menyukai kegiatan kerjasama bersama, memacu untuk saling mengenal secara intim antar sesama warga, dapat saling memahami dan memaklumi perbedaan kepentingan masing-masing warga, mendorong saling menghargai dan menghormati antar sesama warga, dapat mendorong terciptanya kerukunan hubungan antar warga, kedamaian dan dapat memperkuat persatuan warga.

\section{Tradisi Hippun Sebagai Model Pemersatu Masyarakat Multikultural}

\section{Masyarakat Multikultural}

Masyarakat adat Lampung terdiri dari ragam etnis yang memiliki kebiasaan, adat istiadat dan kebudayaan, kelompok kebuwaian (asal keturunan), logat bahasa, dan pemukiman masing-masing yang berbeda. $\mathrm{Di}$ samping adanya perbedaan dalam kalangan masyarakat Lampung sendiri, juga memiliki ciri keragaman multikultur dan etnis atas dasar perbedaan antara pendudk asli dan pendatang. Secara keseluruhan masyarakat Lampung merupakan persatuan masyarakat multikultural, etnis, ras dan asal usul yang berbedabeda, baik perbedaan antara masyarakat adat Lampung asli, maupun perbedaan antara masyarakat adat Lampung dengan masyarakat pendatang. Masyarakat adat Lampung terdiri dari dua golongan adat budaya, yaitu Masyarakat adat Saibatin dan masyarakat adat Pepadun. Sedangkan masyarakat adat pendatang tidak digolongkan tersendiri sebagai masyarakat pendatang, melainkan diterima sebagai bagian dari kedua jurai adat tersebut. Bagi masyarakat pendatang yang bermukim dalam wilayah adat Saibatin, maka mereka (berbagai etnis pendatang) digolongkan sebagai masyarakat adat Saibatin. Begitu juga sebaliknya, bagi mereka (masyarakat pendatang) yang bermukim di wilayah / lingkunagan ada Pepadung, maka mereka diterima sebagai bagian dari masyarakat adat Pepadun.

Pada kebiasannya penggolongan, pengakuan dan penerimaan terhadap masyarakat pendatang ini diawali dengan prosesi adat angkon muwari antara antara kedua belah pihak, baik Saibatin maupun Pepadun. Hal ini dimaksudkan sebagai simbol pemersatu masyarakat multikultural sebagai masyarakat yang nerdamai, rukun dan saling menghargai, menghormati atas perbedaan masingmasing di dalam wilayah pemukinam yang sama. Prosesi muwari ini sesuai dengan prinsip hidup piil pesenggiri, khususnya elemen nemui-nyimah, (ramah dan terbuka) bahwa pada dasarnya adat kebiasaan masyarakat adat Lampung selalu menerima dengan tangan siapa saja, etnis mana saja dan asal usul dari mana saja yang datang hendak hidup bersama bersaudara berdampingan dalam wilayah pemukiman adat yang sama. Model masyarakat multikultural ini berlaku tidak terkecuali pada masyarakat adat jurai Saibating Lampung Selatan, khususnya di wilayah penelitian ini, dimana mereka berbaur hidup 
bersama, berdampingan, dan saling menghargai secara akulturatif, bahkan tela terjadi assimilasi diantara mereka dalam areal pemukinam yang sama.

Seperti diketahui bahwa masyarakat adat Lampung memiliki semboyan/slogan "Sang Bumi Ruwa Jurai" yang artinya "satu bumi dua aliran adat budaya"; kata sang bumi berasal dari "sanga bumi", artinya sebumi. Sedangkan ruwa jurai, artinya dua aliran (kelompok) budaya yang berbeda, yaitu aliran (jurai) masyarakat adat sebatin dan pepadun. Menurut Iwan Nurdaya-Djafar (2014), kata sang menyatakan satu dalam arti kesatuan yang tidak terbagi-bagi, misalnya dalam kalimat sikam sang lamban (kami serumah), ram sang pekon (kita sedesa), dsb. Sedangkan menurut Junaiyah H.M. dalam kata pendahuluan untuk Kamus Bahasa LampungIndonesia yang disusunnya dalam dialek api terdapat kata sanga yang artinya persis sama dengan kata sang yang telah dikemukakan di atas. Dalam Kamus Bahasa Lampung yang disusun oleh Hilman Hadikesuma, kata sanga dalam dialek Pemanggilan dipersamakan dengan kata segalow dalam dialek Tulangbawang yang berarti "semua". Contohnya: sanga muwari, semua saudara; sanga mahhan; seisi rumah. Sama dengan penjelasan Zainudin Hasan (2012), bahwa Sang berarti "satu kesatuan yang utuh". Dalam Bahasa Lampung ada tingkatan satu yang bermakna satu yang berarti kumpulan yaitu kata "Sanga". Sanga berarti kumpulan yang menjadi satu dalam satu wadah atau tempat yang membuatnya menjadi kesatuan yang utuh. Contoh: Sanga karung (satu karung/sekarung), sanga mubil (Satu mobil/Semobil), Sanga kapal (Satu kapal/ sekapal), Sanga menyanak (Satu keluarga/Sekeluarga), Sanga Muari (sepersaudaraan laki-laki)
Sanga Bunakbai (sepersaudaraan perempuan) dan lain-lain.

Sang bumi ruwa jurai merupakan simbol keragaman etnis dan budaya Lampung; sedangkan etnis pendatang tidak digolongkan sebagai jurai ke-3 dalam konsep ini. Dalam simbol budaya Sang Bumi Ruwa Jurai tidak ada kategori ulun Lampung dan pendatang; ini tidak sesuai dengan pemahaman unsur-unsur piil pesenggiri, terutama unsur nemuinyiman. Justeru kelompok pendatang diposisikan sebagai ulun Lampung pada kedua kelompok budaya itu, yaitu pepadun dan sebatin secara bebas dan terbuka, sesuai pilihan, teritorial pemukinan dan penetapan ke dalam warga adat.

Masyarakat adat Sebatin terdiri dari ragam marga yang tersebar di berbagai wilayah Lampung; pada mulanya tersebar di kawasan pesisir pantai, kemudian pada dekade selanjutnya tersebar juga di daerah pedalaman dan sektor perkotaan. Demikian juga sebaliknya masyarakat adat Lampung Pepadun yang umumnya bermukim didaerah pedalaman, kemudian tersebar dan membaur (inkulturasi) dengan kelompok masyarakat lainnya, baik dalam lingkungan 2 (dua) kelompok budaya secara umum, maupun dalam lingkungan jurai marga atau kebuawaian dari masing-masing kelompok budaya tersebut [5].

Masing-masing etnis dalam masyarakat multikultural memiliki kearifan lokal sendiri, seperti etnis Lampung yang dikenal terbuka menerima etnis lain sebagai saudara (adat muwari, angkon muwari/angkat saudara), etnis Batak juga terbuka, Jawa terkenal dengan tata-krama dan perilaku yang lembut, etnis Madura dan Bugis memiliki harga diri yang tinggi, dan etnis Cina terkenal dengan 
keuletannya dalam usaha. Demikian juga etnis-etnis lain seperti, Minang, Aceh, Sunda, Toraja, Sasak, Nias, juga memiliki budaya dan pedoman hidup masing yang khas sesuai dengan keyakinan dan tuntutan hidup mereka dalam upaya mencapai kesejehtaraan berasma. Beberapa nilai dan bentuk kearifan lokal, termasuk hukum adat, nilai-nilai budaya dan kepercayaan yang ada sebagian bahkan sangat relevan untuk diaplikasikan ke dalam proses pembangunan kesejahteraan masyarakat.

Keanekaragaman budaya daerah tersebut merupakan potensi sosial yang dapat membentuk karakter dan citra budaya tersendiri pada masing-masing daerah, serta merupakan bagian penting bagi pembentukan citra dan identitas budaya lokal. Keanekaragaman budaya juga merupakan kekayaan intelektual dan kultural sebagai bagian dari warisan budaya yang perlu dilestarikan. Seiring dengan peningkatan teknologi dan transformasi budaya ke arah kehidupan modern serta pengaruh globalisasi, warisan budaya dan nilai-nilai tradisional masyarakat adat tersebut menghadapi tantangan terhadap eksistensinya. Warisan budaya dan nilai-nilai tradisional ini mengandung banyak kearifan lokal yang masih sangat relevan dengan kondisi saat ini, dan seharusnya dilestarikan, diadaptasi atau bahkan dikembangkan agar nilainilai kearifan lokal tetap relevan dengan kemajuan zaman.

\section{Masalah dalam Masyarakat Multikultural}

Dalam diskusi bersama tokoh-tokoh adat di lokasi penelitian ini dapat disimpulkan ada banyak masalah dalam kehidupan masyarakat multikultural, diantaranya perbedaan- perbedaan antar kelompok, diantaranya perbedaan-perbedaan dalam hal kepentingan, kebiasaan bekerja atau etos kerja, perbedaan profesi/keahlian/ pekerjaan, kelompok etnis, perbedaan status sosial budaya, perbedaan pemilikan lahan, dan lain-lain.

Dalam hal perbedaan kepentingan, dapat menimbulkan perselisihan karena masing-masing pihak tidak ada yang bersedia mengalah, atau karena semua pihak selalu mengutamakan kepentingan pribadi atau kelompoknya, seperti kepentingan pmbangunan jalan kampung, ada yang mengaku penting, ada yang merasa itun tidak prioritas. Begitu juga pebedaan etos kerja dalam tim kerja, seringkali menimbulkan hambatan dan upaya percepatan penyelesaian pekerjaan. Seringkali terjadi konflik antar sesama rekan kerja, sehingga suasana kerja menjadi tidak nyaman, kerukunan menipis, dan persatuan kerja tim menjadi lemah. Perbedaan mata pencaharian juga dapat menimbulkan masalah dalam masyarakat multikultural. Hal ini bisa timbul karena masing-masing pihak lebih memahami, menekun, mengutamakan dan mementingkan setingginya keberhasilan, ketimbang rekannya yang memiliki pekerjaan jenis lain.

Masalah sosial pada umumnya yang timbul karena adanya perbedaan ekonomi masyarakat, yaitu perbedaan penghasilan antar warga masyarakat, ada yang tergolong tinggi, sedang maupun rendah. Bagi warga yang memiliki status ekonomi rendah, tentu kurang atau tidak mampu memenuhi kebutuhan hidup keluarganya secara cukup. Menurut informasi / data hasil penelitian ini duketahui bahwa masyarakat adat setempat pada umumnya hidup pas-pasan dari penghasilan sektor pertanian, di katakan bahwa dalam kurun waktu 10 
tahun terakhir penghasilan masyarakat cenderung menurun drastis. Hal ini akibat dari berkurangnya lahan pertanian karena pembagian warisan, nurahnya harga jual hasil pertanian, khususnya padi sawah, sebagian besar generasi muda putus sekolah dan meneruskan pekerjaan orangbtua sebagai petani kecil dan penggarap, tidak mampu membeli dan menggunakan teknologi bidang pertanian, di samping tidak mampu berpindah ke usaha sektor lain.

Akibat dari rendahnya tingkat kesejahteraan ekonomi masyarakat tersebut antara lain adalah: kemiskinan yang meluas, putus sekolah, kualitas kesehatan menurun, menurunnya keamanan masyarakat dari tindak kejahatan, seperti pencurian, perampokan dll. Kemiskinan yang dialami oleh masyarakat sering mendorong mereka untuk melakukan kejahatan, lantaran tidak dapat mencukupi kebutuhan keluarganya. Dengan tingkat kemiskinan yang terus meningkat, maka akan semakin banyak pula tindakan-tindakan kejahatan yang meresahkan warga.

Masalah lain yang sering timbul dalam masyarakat multikultural adalah prasangka, dan ethosentris. Prasangka (prejudice) adalah anggapan buruk terhadap sesuatu, orang atau pihak lain secara serta merta tanpa pertimbangan terlebih dahulu. Prasangka bisa diartikan suatu sikap yang telampau tergesa-gesa, generalisasi yang terlalu cepat, sepihak, dan meganggap enteng/sepele tentang kenyataan tertentu. Selain prasangka buruk, juga ethosentrisme sebagai sumber masalah dalam masyarakat multikultural, yaitu suatu anggapan yang kecenderungan menilai kebudayaannya sendiri adalah yang terbaik. Anggapan ini seringkali menimbulkan konflik sosial, karena masing-masing kelompok masyarakat yang berbeda etnis sekaligus menganggap buruk terhadap budaya yang dianut oleh etnis lain. Paham etnosentris merupakan kecenderungan tak sadar untuk menginterpretasikan atau menilai kelompok lain dengan tolok ukur kebudayaannya sendiri. Sikap etnosentrisme dalam tingkah laku berkomunikasi nampak canggung, tidak luwes.

Akibat dari dari keberadaan prasangka buruk dan ethnosentrime dalam masyarakat multikultural itu adalah seringnya terjadi pertentangan sosial/ketegangan dan konflik dalam kehidupan masyarakat sehari-hari. Konflik dalam masyarakat multikultural merupakan pertentangan tingkah laku yang lebih luas daripada tafsir ringkas sebagai pertentangan pisik kasar. Konflik merupakan perselisihan/ pertentangan tingkah laku dari pihakpihak yang berbeda emosi, keyakinan dan kepentingan tertentu Perbedaanperbedaan ini sering menimbulkan kebencian atau permusuhan dan konflik.

Menurut data olahan dalam penelitian ini dijelaskan bahwa dirasakan oleh warga telah terjadi pengikisan terhadap persatuan masyarakat atau integrasi sosial. Hal ini dapat dirasakan silitnya mengajak masyarakat bermusyawarah, mencari kata sepakat, dan kerjasama dalam kegiatan gotong royong. Sementara mereka berharap dapat saling mengisi kebutuhan mereka, dapat menciptakan kesepakatan bersama mengenai norma dan nilai sosial yang dilestarikan dan dijadikan pedoman dalam tata kehidupan masyarakat, sehingga mereka dapat hidup rukun, damai dan bersatu.

Adapun yang dapat mengancam integrasi sosial, antara lain adalah unsur tuntutan penguasaan atas 
wilayah-wilayah dan kelompok masyarakat untuk kepentingan elit tertentu, di samping Isu putra daerah asli tidak asli, perbedaan kehidupan ekonomi antar warga, perbedaan Agama dan sentimen agama, di samping terjadi gegar budaya dalam kehidupan masyarakat lokal. Unsurunsur inilah yang sering digerakkan untuk mempertajam perbedaan dan konflik demi kepentingan kekuasaan tertentu.

Gegar budaya juga terjadi dalam kehidupan masyarakat multikultural bersamaan dengan masuknya budaya luar/asing/baru. Gegar budaya atau culture shock yang dimaksud adalah kondisi msyarakat pemangku budaya yang tidak siap menerima budaya baru dalam kehidupannya. Dalam arti lain bahwa kondisi masyarakat yang bingung, bimbang (anomi) akibat masuknya budaya baru secara mendadak (kejutan budaya). Kondisi ini diakui banyak terjadi di daerah lokal seperti daerah sekitar lokasi penelitian, misalnya masyarakat petani yang sebelumnya mengolah sawah dengan bajak ditarik kerbau, kini berganti dengan hadirnya mesin bajak (traktor), akibatnya masyarakat terkejut dan terhenti.

$\mathrm{Di}$ lain pihak terjadi pula ketertinggalan budaya dalam kehidupan masyarakat lokal, di mana dalam pertumbuhan budaya ada bagian-bagian tertentu yang pertumbuhannya lambat (tertinggal). Pada bagian-bagian budaya yang pertumbuhannya lambat ini disebut ketertinggalan kebudayaan (culture lag). Hal ini banyak terjadi, seperti berkembangnya teknologi informasi/komputerisasi, bahwa dalam kenyataannya calon mahasiswa asal daerah terpencil tidak tahu dan tidak bisa mendaftarkan diri via media online. Akibatnya ada yang tidak menjadi peserta test, ada juga yang memanfaatkan jasa online kampus, dan ada yang hanya bisa mendaftar secara manual di Perguruan Tinggu lokal.

Ciri-ciri umum ketertinggalan budaya (culture lag) adalah:

1. Belum menguasai budaya baru

2. Tertutup / menolak terhadap budaya baru

3. Rendah pengetahuan teknologi baru

4. Rendah daya adaptasi terhadap perkembangan teknologi

5. Tidak siap menghadapi perubahan

6 . Rendahnya kontak dengan publik.

\section{Tradisi Hippun sebagai Model Pemersatu Masyarakat}

Masyarakat terbentuk karena beberapa alasan, antara lain adalah adanya dorongan untuk bertahan hidup, yaitu untuk memenuhi kebutuhan hidup akan lebih mudah dengan cara berkelompok. Kemudian karena dorongan untuk kepentingan efisiensi dan efektivitas kerja, yaitu dengan adanya kerjasama dengan pembagian tugas yang jelas, maka akan dapat menghasilkan produk yang bermanfaat maksimal bagi kepentingan bersama. Kelompok sosial sangat penting dalam upaya mewujudkan kesatuan bangsa. Sebagai kelompok sosial dapat mengumpulkan individuindividu dengan adanya tujuan bersama dan dapat memperkuat hubungan kesatuan masyarakat. Dalam kehidupan yang bersatu ini warga masyarakat memiliki kesetiakawanan yang dapat mendorong terciptanya masyarakat yang teratur dan rukun, di mana dapat tercipta kehidupan bersama atas dasar perbedaanperbedaan yang ada. Kerukunan dalam bermasyarakat merupakan tanggung jawab setiap warga, maka nilai-nilai dan norma-norma dalam beretika harus diterapkan dalam kehidupan sehari- 
hari, dengan saling menghargai dan menghormati sesama, agar tercipta kerukunan dalam bermasyarakat. Hal ini digunakan sebagai acuan dalam menyelesaikan masalah yang timbul dalam masyarakat.

Ciri-ciri hippun yang dapat menghasilkan kesepakatan bersama antara lain adalah:

1) Dilaksanakan atas dasar kepentingan bersama;

2) Keputusan hippun harus dapat mewakili/diterima sebagiab besar peserta sesuai aspirasi umum;

3) Gagasan/ide atau pendapat mudah dipahami dan dilaksanakan/terjangkau;

4) Materi hippun atas pertimbangan untuk kebaikan bersama bersumber dari kejujuran dan keterbukaan (transparan).

Dalam proses hippun ada etika perilaku yang harus diimplementasikan dalam kehidupan demokrasi budaya, antara lain dalam penyampaian pendapat, pembuatan keputusan bersama dan dalam mengadakan pengawasan pelaksanaan keputusan bersama, yaitu:

a) Penyampaian pendapat

Dalam penyampaian pendapat selalu bersendi pada akhlak mulia, budi luhur, dan beradab serta menghormati harkat dan martabat sesamanya, sehingga dapat diwujudkan suasana kebersamaan yang menjamin persatuan dan kesatuan bangsa. Dalam penyampaian pendapat tidak mengutamakan kepentingan pribadi atau golongan melainkan mengutamakan terwujudnya keadilan.

b) Pembuatan keputusan bersama Keputusan bersama merupakan kontrak sosial yang harus dipatuhi oleh semua pihak, termasuk pihak yang usulnya tidak disetujui. Keputusan bersama mengikat dan mengandung sanksi. Sikap mau mengakui pendapat yang diputuskan bersama harus dikembangkan.

c) Pengawasan pelaksanaan keputusan bersama

Dalam pengawasan pelaksanaan keputusan bersama pada dasarnya adalah untuk memberikan peringatan dini kepada pelaksana agar dalam melaksanakan tugas bersikap jujur, adil, transparan dan mengutamakan kepentingan bersama.

Kegiatan masyarakat yang menyampaikan pendapat dan pembuat keputusan bersama, para pelaksana kesepakatan bersama dan pengawas pelaksanaan keputusan bersama harus bersinergi sesuai dengan fungsi masing-masing [6].

Penggerakan dan pemberdayaan masyarakat diharapkan dapat menghasilkan kemandirian masyarakat, sehingga masyarakat dapat berperanserta dalam melakukan pemecahan masalahnya sendiri tanpa tergantung pada bantuan dari luar. Peran serta masyarakat adalah rangkaian kegiatan masyarakat yang dilakukan berdasarkan gotong royong dan swadaya masyarakat dalam rangka menolong mereka sendiri mereka sendiri mengenal, memecahkan masalah, dan kebutuhan yang dirasakan masyarakat. Berbagai tingkatan partisipasi masyarakat, yaitu antara lain :

1) Peranserta karena perintah / karena terpaksa.

2) Peranserta karena imbalan. Adanya peranserta karena imbalan tertentu yang diberikan baik dalam bentuk 
imbalan materi atau imbalan kedudukan.

3) Peranserta karena identifikasi atau rasa ingin memiliki

4) Peranserta karena kesadaran. Peranserta atas dasar kesadaran tanpa adanya paksaan atau harapan dapat imbalan

5) Peranserta karena tuntutan hak dan tanggung jawab

Pembinaan peran serta masyarakat dilakukan sebagai upaya pengembangan sumberdaya masyarakat secara berkesinambungan melalui model persuasif dan tidak memerintah, untuk meningkatkan pengetahuan, sikap, perilaku, dan mengoptimalkan masyarakat dalam menemukan, merencanakan, dan memecahkan masalah. Pembinaan lokal merupakan serangkaian langkah yang diterapkan guna menggali, meningkatkan dan mengarahkan peran serta masyarakat setempat. menggunakan sumber daya/potensi yang mereka miliki termasuk partisipasi dan dukungan tokoh-tokoh masyarakat.

Upaya-upaya pemberdayaan masyarakat antara lain adalah sebagai berikut:

1. Menumbuhkan masyarakat

kemampuan

2. Membangun peran serta masyarakat

3. Mengembangkan semangat gotong royong masyarakat

4. Bekerja bersama masyarakat

5. Menggalang kemitraan

6. Penyerahan

pengambilan keputusan kepada masyarakat

Namun demikian tidak dapat dipungkiri bahwa berbagai perbedaan itu dalam perkembangan sejarah kehidupan manusia, pertikaian dan konflik sulit dihindari. Kerukunan masyarakat akan terganggu lantaran tidak diikuti kesadaran yang tinggi dalam berhadapan dengan pola-pola kehidupan modern dihadapannya. Seringkali modernisasi tidak serta merta membuat manusia menjunjung tinggi pentingnya kerukunan, melainkan tumbuhnya pola pikir subyektif yang dapat menimbulkan konflik.

Menurut adat istiadat Lampung, khususnya dalam lingkungan masyarakat adat Buwai Khunjung, tradisi hippun dalam setiap perencanaan, pembinaan kerukunan, persatuan warga dan penanganan konflik yang terjadi. Dengan hippun dapat mendorong terciptanya kerukunan, perdamaian dan penguatan ikatan persatuan warga masyarakat. Adapun ciri persatuan masyarakat, antara lain adalah adanya kebersamaan, kesetiakawanan, kesenasiban, kerelaan berkorban dan adanya kesadaran dalam hidup bermasyarakat, sehingga timbul keinginan untuk selalu membantu sesama. Menurut informan tokoh adat setempat bahwa kegiatan hippun dapat memelihara perdamaian dan persatuan masyarakat, yaitu dengan mengawasi dan menegakkan kesepakatan keputusan hippun agar dapat dihormati dan dilaksanakan. Dengan hippun juga dapat memotivasi masyarakat berdamai: yaitu melaksanakan keputusan hippun dengan mengajak warga bersama-sama agar lebih terpercaya dan dapat meningkatkan stabilitas dan keadilan masyarakat. Kecuali itu dijelaskan bahwa dengan hippun dapat menciptakan persatuan masyarakat, di mana meskipun diterpa oleh berbagai bentuk intervensi atau pengaruh budaya modern, akan tetapi masyarakat tidak goyah dan tetap bersatu

Menurut data hasil penelitian olahan dapat dirumuskan bahwa 
terdapat beberapa kegunaan hippun bagi masyarakat, sehingga dalam setiap rencana, usaha dan penyelesaian masalah selalu berdasarkan atas keputusan hippun. Kegunaan-kegunaan hipuun itu antara adalah:

1) berguna dalam kemudahan menyalurkan aspirasi, di mana gagasan dapat disampaikan dan dibahas dalam rangka pemecahan masalah. Di samping itu hippun dapat melatih kebiasaan mengemukakan pendapat yang berguna sebagai bahan pertimbangan dalam mencari jalan pemecahan masalah;

2) berguna bagi masyarakat dalam mempercepat pemecahan masalah, yaitu dapat segera menemukan alternatif model penyelesaian masalah, khususnya yang menyangkut kepentingan bersama;

3) keputusan hiipun dianggap bermanfaat bagi masyarakat karena dirasakan ada keadilan, dimana hippun sebagai proses penjaringan aspirasi merupakan bahan kesepakatan bersama sesama anggota. Kesepakatan bersama ini dapat dilaksanakan dengan mudah karena didasarkan sukarerela tanpa paksaan;

4) keputusan hippun berguna bagi masyarakat, terutama dirasakan dapat mempersatukan pendapat yang berbeda-beda. Diakui bahwa hampir setiap hippun menghasilkan kesepakatan yang intinya menghapuskan berbagai perbedaan yang ada, sehingga kerukunan warga tetap terpelihara, di samping dapat menghasilkan keputusan yang benar yang dapat diterima oleh semua pihak dan terhindar dari kekeliruan dalam bertindak;

5) dengan kebiasaan ikutserta dalam hippun dapat menciptakan stabilitas emosional warga, di mana semua pihak terbiasa mengutamakan kepentingan bersama, sehingga hasil keputusan bersama dapat diterima dan dilaksanakan dengan penuh tanggung jawab.

Dari beberapa kegunaan/manfaat hippun yang dirasakan masyarakat, kemudian mendorong mereka untuk selalu hidup rukun, damai dan bersatu. Meskipun mereka terdiri dari kumpulan berbagai kelompok masyarakat yang berbeda, akan tetapi saling menghargai dan saling menghormati dan bersatu dalam satu lingkungan sosial pemjkiman yang sama. Persatuan masyarakat ini nampak dari unsur kebersamaan dan kesamaan tujuan hidup dan tunduk pada hasil keputusan yang sama. Meskipun mereka terdiri dari beraneka ragam suku dan hudaya, tapi mereka memiliki kesadaran sebagai satu kesatuan yang damai dan rukun. Persatuan masyarakat ini diikat oleh adanya kesamaan kepentingan, dan dari persamaan kepentingan membuat persatuan masyarakat semakin erat. Persatuan masyarakat ini juga ditandai adanya saling interaksi antar warga, yaitu terdapatnya hubungan antar anggota masyarakat secara langsung, intim dan intensif.

Terpeliharanya kedamaian, kerukunan dan persatuan masyarakat itu, menurut hasil penelusuran lapangan, diketahui bahwa kuncinya adalah terletak pada ketergantungan dan kepercayaan masyarakat terhadap tradisi hippun, terpeliharanya rutinitas dan kualitas pelaksanaan hippun bersama keputusan yang dihasilkan, terpeliharanya kehendak bersama melembagakan hippun sebagai satusatunya wadah untuk mencapai kepetingan bersama, di samping terjaganya keberhasilan fungsi hippun sebagai cara penyelesaian masalah. 
Sumberdaya yang menopang meningkatnya keterikatan emosional masyarakat terhadap tradisi hippun sebagai media ampuh dalam upaya memelihara kerukunan dan persatuan masyarakat adalah sistem 5 unsur prinsip hidup, khususnya bagi masyarakat adat Buwai Khunjung. Sistem 5 (lima) unsur prinsip hidup ini adalah sebagai berikut:

1. Uttung-sebagi : setiap ada keuntungan hasil kerjasama selalu berbagi secara Jujur dan terbuka

2. Utang-sebayakh : setiap transaksi utang piutang selalu didasari niat hendak membayar dalam waktu yang tepat

3. Semaya-setunggu : Setiap berjanji selalu ditepati, ada kepastian waktu dan tempat serta dapat ditunggu dalam waktu tidak terlalu lama

4. Hippun-nufakat : Segala urusan yang menyangkut kepentingan bersama, selalu Selalu diselesaikan melalui lembaga hippun

5. Ukhik-sepati : Dalam hifup bersama sebuwai, sepekon dan sesuku bersumpah setia sampai mati tidak khianat.

Atas dasar kegunaan hippun yang dirasakan bertahun berabad oleh masyarakat adat, maka mereka terbiasa dan terikat untuk selalu melaksanakan hippun setiap upaya bertahan hidup. Sudah menjadi tradisi, bahkan menjadi adat istiadat, bahwa setiap ada rencana yang berkaitan dengan kebijakan aah pembangunan, maka lazim dilaksanakan penjaringan aspirasi/pendapat warga melaui kegiatan hippun. Demikian pula dengan upaya penanganan perselisihan/konflik pada umumnya selalu dilakukan penyelesaian dengan cara hippun, dan sampai saat ini diakui berhasil membawa perdamaian.

Dalam berbagai kegiatan adat, mulai dari kegiatan upacara adat perkawinan, angkon muwari, tetah adok, ngelakau, ngarak maju, deduwaian, manjau, nyambai, penyelesaian konflik sebambangan, cakak saituha, pelamaran, sampai pada acara perkumpulan keluarga/kerabat dan warga masyarakat, selalu diawali dengan kegiatan hippun. Dengan hippun semua kegiatan usaha mencapai mupakat, kerukunan dan persatuan masyarakat dapat dicapai dengan efektif.

Dalam hal kegiatan yang berkaitan dengan mata pencaharian, khususnya dibidang pertanian, pada umumnya juga selalu dimulai dengan hippun, seperti kegiatan pembukaan lahan, ngusi (pembersihan lahan), myuwah (pembakaran ranting dan sampah), menyemai benih, penanaman, sampai pada kgiatan sesakaian (tolong menolong) panen hasil pertanian dan penyimpanan hasil panen (padi). Demikian juga dalam hal upaya pemeliharaan kebersamaan, kerukunan dan persatuan masyarakat selalu, bahkan harus diawali dengan hippun. Dengan kata lain bahwa hippun diakui dan diyakiniwarga sebagai satusatunya model dalam upaya pemeliharaan, peningkatan dan mengawasi stabilitas kerukunan dan persatuan masyarakat, tidak terkecuali terhadap masyarakat yang multi kultural.

Masyarakat adat pada lingkungan marga Legun dan masyarakat adat Buwai Runjung percaya, yakin dan patuh terhadap tradisi hippun, karena dirasakan manfaatnya dapat menyelesaikan segala masalah yang timbul, di samping menurut pengalaman mereka dapat menjamin terciptanya kerukunan sebagai sumber 
daya terciptanya persatuan masyarakat. Atas dasar kenyataan ini, maka cukup beralasan bahwa yradisi hippun ini dapat dijadikan model dalam upaya mempersatukan masyarakat, terutama masyarakat multikultural lokal sebagaimana kondisi keragaman masyarakat Lampung pada umumnya, baik dalam lingkup multikultur Sang Bumi Ruwa Jurai, maupun multikultur dalam lingkup seluruh penduduk lokal dan pendatang dari berbagai etnis dan budaya yang hidup menetap bersama di Lampung..

\section{Upaya Pelestarian Pengembangan Tradisi Hippun}

dan

Dalam rangka pelestarian tradisi hippun perlu dibentuk Lembaga Hippun Pemekonan sebagaimana di Pekon-pekon lain di Lampung. Lembaga Hippun Pemekonan (LHP) atau Badan Hippun Pemekonan (BHP) adalah:

1. BHP adalah sebutan lain dari badan permusyawaratan desa (BPD) merupakan lembaga perwujudan demokrasi dalam penyelenggaraan pekon. (Montesquieu, dalam Kansil (2008: 9)

2. BHP adalah sebagai unsur penyelenggara pemerintahan Desa yang dibentuk berdasarkan usulan masyarakat Desa yang bersangkutan.

Undang-Undang Nomor 6 Tahun 2014 tentang Desa menggeser posisi Badan Permusyawaratan Desa (BPD) sebagai unsur penyelenggara pemerintahan desa menjadi lembaga desa. Sebagai lembaga desa, fungsi dan kedudukan BPD semakin jelas, yaitu lembaga legislatif desa yang mengusung mandat untuk menyalurkan aspirasi, merencanakan anggaran, dan mengawasi pemerintahan desa.

Melaksanakan pengawasan terhadap pelaksanaan peraturan Pekon dan peraturan Peratin.Tujuan pembentukan LHP/ BHP adalah sebagai berikut:

1. Sebagai tempat Menyerap, menampung, menghimpun dan menindaklanjuti aspirasi masyarakat.

2. Menghormati nilai-nilai sosial budaya dan adat istiadat masyarakat setempat.

3. Menggali, menampung, menghimpun, merumuskan dan menyalurkan aspirasi masyarakat.

4. sudah Mengayomi, yaitu dengan menjaga kelestarian adat istiadat yang hidup dan berkembang di Desa Insil.

5. Tujuan Pembentukan Lembaga Masyarakat Desa adalah untuk memperkuat Pemerintahan Desa serta mewadahi perwujudan pelaksanaan Demokrasi Pancasila di Desa.

6. Memberikan pedoman bagi anggota masyarakat bagaimana mereka bertingkah laku atau bersikap sesuai dengan kedudukannya dalam menghadapi masalah dalam masyarakat yang berhubungan dengan kebutuhan masyarakat.

7. Menjaga masyarakat agar tetah utuh

8. Memberikan pedoman bagi masyarakat untuk membuat sistem pengendalian sosial, seperti sistem pengawasan masyarakat terhadap tingkah laku anggotanya

9. Sebagai tempat demokrasi desa, anggota BHP dipilih dari dan oleh penduduk desa yang telah memenuhi persyaratan. Sedangkan pimpinan BHP dipilih dari dan oleh anggota BHP sendiri.

Atas dasar tujuan, maka cukup beralasan perlunya upaya pelestarian 
tradisi hippun sebagai model pemersatu masyarakat multikultural. Khususnya di lingkungan masyarakat adat Marga Legun dan Buwai Khunjung.Upaya pelestarian ini adalah perlu dengan segera membentuk Lembaga Hippun Pemekonan atau Badan Hippun Pemekonan, sebagaimana daerah lainnya, seperti pekon-pekon di Kabupeten Tanggamus.

Untuk mendukung pelestarian hippun dengan membentuk LHP/BHP tersebut, juga perlu penggalakan, pendekatan kepada masyarakat dengan melakukan jaring aspirasi untuk mengetahui seberapa besar keterikatan atau penolakan masyarakat terhadap tradisi hippun. Melalukan sosialisassi tentang nilai dan manfaat pelestarian tradisi hippun. Hal ini perlu untuk menetapkan langkah-langkah, strategi dan materi prioritas yang diperlukan dalam sosialisasi. Pembiasaan mengajak warga masyarakat pada setiap perencanaan, penjaringan pendapat tentang kebijakan tertentu, dan lebih penting lagi adalah implementasi atau kesepakatan hippun secara nyata agar warga tertarik dan percaya.

Sehubungan dengan pembentukan Lembaga Hippun Pemekonan, maka perlu juga dikembangkan dengan melakukan sosialisasi tentang manfaatnya kepada masyarakat adat di lingkungan Pemerintahan Adat khususnya Marga Legun dan Buwai Khunjunag. Menurut Lembaga Hippun Pemekonan bentukan Pemeritah Daerah Kabupaten Tanggamus, diantara manfaatnya adalah:

1. Mempertahankan dan memelihara hukum nasional sera keutuhan NKRI

2. Menjaga norma dan etika dalam hubungan kerja dengan lembaga kemasyarakatan
3. Mengamalkan melaksanakan mentaati perundang-undangan

pancasila, 1945 dan peraturan

4. Melaksanakan kehidupan demokrasi dalam pemerintahan Pekon

5. Sebagai tempat Menyerap, menampung, menghimpun dan menindaklanjuti aspirasi masyarakat

6. Melaksanakan pengawasan terhadap pelaksanaan peraturan Pekon dan peraturan Peratin.

7. Membahas dan menyepakati rancangan Peraturan Desa bersama Kepala Desa;

8. Menyelenggarakan musyawarah Desa;

9. Membentuk panitia pemilihan Kepala Desa;

Dari beberapa kegunaan/manfaat hippun yang dirasakan masyarakat, kemudian mendorong mereka untuk selalu hidup rukun, damai dan bersatu. Meskipun mereka terdiri dari kumpulan berbagai kelompok masyarakat yang berbeda, akan tetapi saling menghargai dan saling menghormati dan bersatu dalam satu lingkungan sosial pemjkiman yang sama. Persatuan masyarakat ini nampak dari unsur kebersamaan dan kesamaan tujuan hidup dan tunduk pada hasil keputusan yang sama. Meskipun mereka terdiri dari beraneka ragam suku dan hudaya, tapi mereka memiliki kesadaran sebagai satu kesatuan yang damai dan rukun. Persatuan masyarakat ini diikat oleh adanya kesamaan kepentingan, dan dari persamaan kepentingan membuat persatuan masyarakat semakin erat.

Atas dasar kegunaan . manfaat hippun seperti telah dipaparkan di atas, maka perlu dilakukan pengembangan tradisi hippun sebagai odel pemersatu masyarakat multikultural. Diantara 
upaya-upaya itu adalah dengan pemberdayaan masyarakat yaitu:

1. Menumbuhkan kemampuan masyarakat

2. Membangun peran serta masyarakat

3. Mengembangkan semangat gotong royong masyarakat

4. Bekerja bersama masyarakat

5. Menggalang kemitraan

6. Penyerahan pengambilan keputusan kepada masyarakat

Di samping itu dalam berbagai kegiatan adat, mulai dari kegiatan upacara adat perkawinan, angkon muwari, tetah adok, ngelakau, ngarak maju, deduwaian, manjau, nyambai, penyelesaian konflik sebambangan, cakak saituha, pelamaran, sampai pada acara perkumpulan keluarga/kerabat dan warga masyarakat, selalu diawali dengan kegiatan hippun masingmasing. Cara lain adalah dengan melakukan simulasi atas kegiatankegiatan adat, diharapkan mendorong hippun pada setiap ditemukan kekurangan atau ketidaktahuan dalam prosesi simulasi adat itu.

Untuk mendukung upaya pengembangan hippun, perlu juga melalukan sosialisassi tentang manfaat kegiatan hippun. Dalam praktiknya dengan mmengajak warga masyarakat pada setiap hippun perencanaan, penjaringan aspirasi kebijakan pemekonan, di samping melibatkan warga dalam penerapan keputusan hippun secara nyata di tengah-tengah pemekonan.

\section{Kesimpulan}

Menurut adat istiadat Lampung, khususnya dalam lingkungan masyarakat adat Buwai Khunjung, adat tradisi hippun dalam setiap perencanaan, pembinaan kerukunan, persatuan warga dan penanganan konflik yang terjadi. Dengan hippun dapat mendorong terciptanya kerukunan, perdamaian dan penguatan ikatan persatuan warga masyarakat. Adapun ciri adanya persatuan masyarakat, antara lain adalah adanya kebersamaan, kesetiakawanan, kesenasiban, kerelaan berkorban dan adanya kesadaran dalam hidup bermasyarakat, sehingga timbul keinginan untuk selalu membantu sesama. Menurut informan tokoh adat setempat bahwa kegiatan hippun dapat memelihara perdamaian dan persatuan masyarakat, yaitu dengan mengawasi dan menegakkan kesepakatan keputusan hippun agar dapat dihormati dan dilaksanakan. Dengan hippun juga dapat memotivasi masyarakat berdamai: yaitu melaksanakan keputusan hippun dengan mengajak warga bersama-sama agar lebih terpercaya dan dapat meningkatkan stabilitas dan keadilan masyarakat. Kecuali itu dijelaskan bahwa dengan hippun dapat menciptakan persatuan masyarakat, di mana meskipun diterpa oleh berbagai bentuk intervensi atau pengaruh budaya modern, akan tetapi masyarakat tidak goyah dan tetap bersatu.

Terpeliharanya kedamaian, kerukunan dan persatuan masyarakat itu, menurut hasil penelusuran lapangan, diketahui bahwa kuncinya adalah terletak pada ketergantungan dan kepercayaan masyarakat terhadap tradisi hippun, terpeliharanya rutinitas dan kualitas pelaksanaan hippun bersama keputusan yang dihasilkan, terpeliharanya kehendak bersama melembagakan hippun sebagai satusatunya wadah untuk mencapai kepetingan bersama, di samping terjaganya keberhasilan fungsi hippun sebagai cara penyelesaian masalah. 
Sumberdaya yang menopang meningkatnya keterikatan emosional masyarakat terhadap tradisi hippun sebagai media ampuh dalam upaya memelihara kerukunan dan persatuan masyarakat adalah sistem 5 unsur prinsip hidup, yaitu : 1) Uttung-sebagi; 2) Utang-sebayakh; 3) Semayasetunggu; 4) Hippun-nufakat; dan 5) Ukhik-sepati.

Atas dasar kegunaan hippun yang dirasakan bertahun berabad oleh masyarakat adat, maka mereka terbiasa dan terikat untuk selalu melaksanakan hippun setiap upaya bertahan hidup. Sudah menjadi tradisi, bahkan menjadi adat istiadat, bahwa setiap ada rencana yang berkaitan dengan kebijakan aah pembangunan, maka lazim dilaksanakan penjaringan aspirasi/pendapat warga melaui kegiatan hippun. Demikian pula dengan upaya penanganan perselisihan/konflik pada umumnya selalu dilakukan penyelesaian dengan cara hippun, dan sampai saat ini diakui berhasil membawa perdamaian.

Masyarakat adat pada lingkungan marga Legun dan masyarakat adat Buwai Runjung percaya, yakin dan patuh terhadap tradisi hippun, karena dirasakan manfaatnya dapat menyelesaikan segala masalah yang timbul, di samping menurut pengalaman mereka dapat menjamin terciptanya kerukunan sebagai sumber daya terciptanya persatuan masyarakat. Atas dasar kenyataan ini, maka cukup beralasan bahwa yradisi hippun ini dapat dijadikan model dalam upaya mempersatukan masyarakat, terutama masyarakat multikultural sebagaimana kondisi keragaman masyarakat Lampung pada umumnya, baik dalam lingkup multikultur Sang Bumi Ruwa Jurai, maupun multikultur dalam lingkup seluruh penduduk lokal dan pendatang dari berbagai etnis dan budaya yang hidup menetap bersama di Lampung.

Kegunaan-kegunaan hippun itu antara adalah: 1) berguna dalam kemudahan menyalurkan aspirasi, di mana gagasan dapat disampaikan dan dibahas dalam rangka pemecahan masalah. Di samping itu hippun dapat melatih kebiasaan mengemukakan pendapat yang berguna sebagai bahan pertimbangan dalam mencari jalan pemecahan masalah; 2) berguna bagi masyarakat dalam mempercepat pemecahan masalah, yaitu dapat segera menemukan alternatif model penyelesaian masalah, khususnya yang menyangkut kepentingan bersama; 3) keputusan hippun dianggap bermanfaat bagi masyarakat karena dirasakan ada keadilan, dimana hippun sebagai proses penjaringan aspirasi merupakan bahan kesepakatan bersama sesama anggota. Kesepakatan bersama ini dapat dilaksanakan dengan mudah karena didasarkan sukarerela tanpa paksaan; 4) keputusan hippun berguna bagi masyarakat, terutama dirasakan dapat mempersatukan pendapat yang berbeda-beda. Diakui bahwa hampir setiap hippun menghasilkan kesepakatan yang intinya menghapuskan berbagai perbedaan yang ada, sehingga kerukunan warga tetap terpelihara, di samping dapat menghasilkan keputusan yang benar yang dapat diterima oleh semua pihak dan terhindar dari kekeliruan dalam bertindak; 5) dengan kebiasaan ikutserta dalam hippun dapat menciptakan stabilitas emosional warga. Semua pihak terbiasa mengutamakan kepentingan bersama, sehingga hasil keputusan dapat diterima dan dilaksanakan dengan penuh tanggung jawab.

Dari beberapa kegunaan/manfaat hippun yang dirasakan masyarakat, 
kemudian mendorong mereka untuk selalu hidup rukun, damai dan bersatu. Meskipun mereka terdiri dari kumpulan berbagai kelompok masyarakat yang berbeda, akan tetapi saling menghargai dan saling menghormati dan bersatu dalam satu lingkungan sosial pemjkiman yang sama. Persatuan masyarakat ini nampak dari unsur kebersamaan dan kesamaan tujuan hidup dan tunduk pada hasil keputusan yang sama. Meskipun mereka terdiri dari beraneka ragam suku dan hudaya, tapi mereka memiliki kesadaran sebagai satu kesatuan yang damai dan rukun. Persatuan masyarakat ini diikat oleh adanya kesamaan kepentingan, dan dari persamaan kepentingan membuat persatuan masyarakat semakin erat. Persatuan masyarakat ini juga ditandai adanya saling interaksi antar warga, yaitu terdapatnya hubungan antar anggota masyarakat secara langsung, intim dan intensif. Dengan kegunaan ini, maka cukup beralasan perlunya upaya pelestarian tradisi hippun sebagai model pemersatu masyarakat multikultural. Khususnya di lingkungan masyarakat adat Marga Legun dan Buwai Khunjung.Upaya pelestarian ini adalah perlu dengan segera membentuk Lembaga Hippun Pemekonan atau Badan Hippun Pemekonan, sebagaimana daerah lainnya, seperti pekon-pekon di Kabupeten Tanggamus [7].

Undang-Undang Nomor 6 Tahun 2014 tentang Desa menggeser posisi Badan Permusyawaratan Desa (BPD) sebagai unsur penyelenggara pemerintahan desa menjadi lembaga desa. Sebagai lembaga desa, fungsi dan kedudukan BPD semakin jelas, yaitu lembaga legislatif desa yang mengusung mandat untuk menyalurkan aspirasi, merencanakan anggaran, dan mengawasi pemerintahan desa.
Melaksanakan pengawasan terhadap pelaksanaan peraturan Pekon dan peraturan Peratin.

Tujuan pembentukan LHP/ BHP adalah sebagai berikut:

1. Sebagai tempat Menyerap, menampung, menghimpun dan menindaklanjuti aspirasi masyarakat.

2. Menghormati nilai-nilai sosial budaya dan adat istiadat masyarakat setempat.

3. Menggali, menampung, menghimpun, merumuskan dan menyalurkan aspirasi masyarakat.

4. sudah Mengayomi, yaitu dengan menjaga kelestarian adat istiadat yang hidup dan berkembang di Desa Insil.

5. Tujuan Pembentukan Lembaga Masyarakat Desa adalah untuk memperkuat Pemerintahan Desa serta mewadahi perwujudan pelaksanaan Demokrasi Pancasila di Desa.

6. Memberikan pedoman bagi anggota masyarakat bagaimana mereka bertingkah laku atau bersikap sesuai dengan kedudukannya dalam menghadapi masalah dalam masyarakat yang berhubungan dengan kebutuhan masyarakat.

7. Menjaga masyarakat agar tetah utuh

8. Memberikan pedoman bagi masyarakat untuk membuat sistem pengendalian sosial, seperti sistem pengawasan masyarakat terhadap tingkah laku anggotanya

9. Sebagai tempat demokrasi desa, anggota BHP dipilih dari dan oleh penduduk desa yang telah memenuhi persyaratan. Sedangkan pimpinan BHP dipilih dari dan oleh anggota BHP sendiri.

Untuk mendukung pelestarian hippun dengan membentuk LHP/BHP tersebut, juga perlu penggalakan, 
pendekatan kepada masyarakat dengan melakukan jaring aspirasi untuk mengetahui seberapa besar keterikatan atau penolakan masyarakat terhadap tradisi hippun. Melalukan sosialisassi tentang nilai dan manfaat pelestarian tradisi hippun. Hal ini perlu untuk menetapkan langkah-langkah, strategi dan materi prioritas yang diperlukan dalam sosialisasi. Pembiasaan mengajak warga masyarakat pada setiap perencanaan, penjaringan pendapat tentang kebijakan tertentu, dan lebih penting lagi adalah implementasi atau kesepakatan hippun secara nyata agar warga tertarik dan percaya. Dengan demikian dapat dimengerti bahwa jika Kepala Adat bersama perangkat adatnya dengan berkesinambungan melakukan pelestarian tradisi hippun, maka dengan mudah dapat mempertahankan dan memperkuat krukunan antar tokoh adat dan persatuan warga masyarakat.

Atas dasar kegunaan hippun seperti telah dipaparkan di atas, maka perlu dilakukan pengembangan tradisi hippun sebagai model pemersatu masyarakat multikultural. Diantara upaya-upaya itu adalah dengan pemberdayaan masyarakat yaitu:

1. Menumbuhkan kemampuan masyarakat;

2. Membangun peran serta masyarakat

3. Mengembangkan semangat gotong royong masyarakat

4. Bekerja bersama masyarakat
5. Menggalang kemitraan

6. Penyerahan pengambilan keputusan kepada masyarakat

\section{Referensi}

[1] A. Syani, 2010. [Online]. Available: http://blog.unila.ac.id/abdulsyani/.

[2] A. Syani, "Nilai Nilai Budaya Bangsa dan Kearifan Lokal," 2012.

[3] A. Syani, "Implementasi NilaiNilai Piil Pesenggiri dalam Membangun Kemandirian Desa (Disampaikan pada kegiatan pembekalan Kulaih Kerja Nyata (KKN) Mahasiswa berbasis Kebangsaan Di Pangkalan TNI AL (LANAL) Lampung, Piabung, Kab. Pesawaran)." 2018.

[4] N. A. Ridwan, "Landasan Keilmuan Kearifan Lokal," IBDA, P3M Stain, vol. 5, no. 1, 2007.

[5] A. Syani, "Makalah Kearifan Lokal Sebagai Aset Budaya Bangsa Dan Implementasinya Dalam Kehidupan Masyarakat," Diklat Bidik Misi Di Universitas Lampung, 2013.

[6] A. Syani, "Makalah Seminar Budaya Tentang Pendekatan Sosial Budaya," 2010.

"Peraturan Daerah Kabupaten Tanggamus Nomor 13 Tahun 2006 Tentang Badan Hippun Pemekonan." 
Abdul Syani dkk. : Tradisi "Hippun" Sebagai Model Permersatu Masyarakat Multikultural (Studi Pada Penduduk Ragam Etnis Dan Budaya Di Wilayah Kabupaten Lampung Selatan) 